\title{
FAILURE IN CONTRACTS IN NIGERIAN CONSTRUCTION PROJECTS: CAUSES AND PROFFERED POSSIBLE SOLUTIONS
}

\author{
Stephen Bamidele Obebe ${ }^{1}$, Abdullahi Kolo ${ }^{2}$, Idrisu Sulaiman Enagi3, Abdullahi Audu Adamu ${ }^{4}$ \\ ${ }^{1,4}$ Department of Mechanical Engineering, Bayero University Kano, P.M .B. 3011, Kano Nigeria. \\ ${ }^{2}$ Department of Engineering Services, Niger State Agricultural Mechanization and Development \\ Authority, P. M. B.132, Minna, Niger State, Nigeria. \\ ${ }^{3}$ Department of Mechanical Engineering, Federal University of Technology, Minna, P.M .B. 65, Minna, \\ Niger State, Nigeria.
}

\begin{abstract}
Nigerians and other expatriates residing in the country cannot continue to fold their arms and being deprived of enjoying buildings and other engineering infrastructural development projects such as houses, churches, schools, roads, bridges, tunnels, dams, seaport, airport, hotels etc. due to construction failures. Failed projects is rampant everywhere in the country in which the citizens have no good access to quality infrastructure which is critical for a decent standard of living and good sustainability. The cases of failed projects is affecting the construction industry and the national economy. This paper discusses and identifies the main causes of failures of contracts in the Nigerian construction industry and the proffered possible solutions based upon the experience from the Nigerian construction industry. The objective of this research was achieved by means of questionnaire survey and statistical analysis of the data collected.
\end{abstract}

Keywords - Construction Industry/Firm, Contracts/Projects Failure, Abandoned// Failed Projects, Construction Projects, Contract Document, Project Delivery Time, Project Delivery, Statistical Analysis, Nigerian.

\section{INTRODUCTION}

Construction is a product-oriented activity that has many dimensions. One of these dimensions is the business side of construction. The business world is structured by contractual relationship, and the business aspects of construction require the establishment of contractual relationships with a wide range of parties. The central role played by contracts is reflected by the fact that construction firms are referred to as "contractors". In addition to the contractual relationship with the owner/client, construction managers supervise contracts with subcontractors, especially with firms such as scheduling services, labour union, as well as equipment and materials vendors. Insurance and bonds as well as the document establishing the legal structure of a company have the elements of contractual requirements. There are different contractual forms used to establish contracts for the construction of projects. An agreement between two or more competent parties to do something for a consideration establishes the basis for a contract. What is agreed to perform (or refrained from being performed) cannot be impossible or enjoined by law. For example, a contract cannot bind a party to perform an illegal act or one that would be virtually impossible such as completing a 20 -storey building in a week. The courts are often called upon to determine: 1.) Who are the parties to a contract? 2.) What are their promises? 3.) Other aspects of the Contractual agreement (Halpin and Senior, 2012).

According to Nagarajan (2012), a contract is a legal agreement. It is an exchange of promises by two or more persons. Section 2 (b) of the Indian Contract Act, 1872 defines contract as "an agreement enforceable by law". The definition given by the Indian Contract Act as two distinct parts. They are: a.) a contract is an agreement b.) the agreement must be one enforceable by law. Thus, though contract is necessarily an agreement, all agreements are not contracts. Only those agreements that are enforceable by law are contracts. For an agreement to become enforceable by law, it must satisfy certain essential elements called "essentials" of valid contract". The contractor is a person, a firm or a company who undertakes contract.

According to Sasi Kumar and Divakar (2018), the construction business is large in size and it is of great importance in the role it plays in the 
economy of the nation but through recent years it has witnessed an increasing number of construction financial failures. The failure of a company may cause expensive losses to the business community and also to society. In particular, it may affect various stakeholders, such as investors, creditors, shareholders or employees.

Construction is always an extremely competitive business. That fact is not limited to territory or project type. With limited local opportunities available to some contractors, expanding beyond their territory or normal scope of work becomes attractive, but that injects additional risks. There are large numbers of contractors in the country and it is easy to establish a new firm. Due to people's belief in high profit, the construction industry has attracted many people, but when they enter the business, they will feel the difficulty and complexity of it. A number of studies have been conducted to address and control the problems of the industry in the developing countries. However, these was no much progression in solving such problems due to many reasons (Sasi Kumar and Divakar, 2018). Nigeria is blessed with great potentials in building and construction industry which is enough to boost and enhance our economy by constituting a high percentage, but today it is unfortunate that abandoned projects and construction projects failure has littered every part of the country. Not only that, our heavy manufacturing industries such as Nigerian Paper Mill Jebba in Kwara State, Nigerian Sugar Company Limited Bacita in Kwara State, Ajaokuta Iron and Steel Company Limited in Ajaokuta, Kogi State etc are no more functioning in such situation that they have become failed and abandoned for many years in which the equipment and facilities that were being used in production processes have become obsolete and deteriorated. But, it is believed that the Federal Government is working towards the revival of these companies.

According to Umsohi and Imaroh (2020), every company in the face of the times will always develop and try to achieve better targets than before by getting involved all the elements and components that play a role in the company. Of course, every component in the company has its own respective strategies in achieving the vision of the company, especially the special division or section that plays a direct role with the information system because it is directly dealing with the advancement of information technology that is very fast developing.

\section{LITERATURE REVIEW}

Construction industry is the engine that drives the overall economy. It represents one of the largest economic sectors in the United States. Until the early 1980s, the construction industry accounted for the largest percentage of the gross domestic product (GDP) and had the highest dollar turnover of any U.S industry. Presently, construction is still the largest manufacturing industry in the United States. New construction accounts for approximately $8 \%$ of the GDP and retrofit projects contribute an additional $5 \%$. More than a million firms operate in the construction sector, and the number of people employed in construction is estimated to be 10 million. The industry consists of large and small firms. The largest firms may have an annual work volume in excess of $\$ 20$ billion, and consist of thousands of employees. Many of the largest firms work both domestically and in the international market. In contrast to the large companies, statistics indicate that over two -thirds of construction related firms have less than five employees. The spectrum of work ranges from the construction of large power plants and inter-state highways costing billions of dollars to the construction of single-family houses and paving of driveways and sidewalks (Halpin and Senior, 2012).

In Nigeria today, there are several top construction companies which have demonstrated a huge success when it comes to timely project delivery and efficiency such as Julius Berger Nigeria Plc, Reynolds Construction Company (RCC) Nigeria limited, Sethraco Nigeria Limited, Constain West African Plc, Monia Construction Company Nigeria Limited, Brunelli Construction Company Nigeria Limited, Dantata and Sawoe Construction Company Nigeria Limited, Mother Cat Construction Company Nigeria Limited, Triacta Construction Company Nigeria Limited, Bulletin Construction Company Nigeria Limited, China Civil Engineering Company (CCEC) Nigeria Limited, Gitto Construction Company Limited etc. But the most unfortunate aspects of construction work in Nigeria, with all the construction industries mentioned above, abandonee projects; construction/contract failures; on-going projects (to be completed next some years); revocation of contracts etc is rampant in the country. These failures cannot boost the economy but can cause economic depression, it may demoralize and affect the various stakeholders such as employees, shareholders, investors etc. An important question we need to ask ourselves is that "who is to be blamed on contract/construction projects failure?", is it the client (Federal Government, State Government, individuals) or the contractors (construction companies)? 


\section{International Journal of Engineering Applied Sciences and Technology, 2020}

Vol. 5, Issue 2, ISSN No. 2455-2143, Pages 679-692

Published Online June 2020 in IJEAST (http://www.ijeast.com)

The most important measures of project failure are poor quality, cost overrun, and time overrun. Findings showed that contracts should only be awarded if funds are available at the procurement stage. The mission of construction is constrained in terms of the available time and amount of available funds. For any agreed and signed project contracts to be executed, funds has to be released to initiate the project. This funds released may be instalmental payment, part payment or full payment. If it is part payment, then it has expiring date to avoid the ongoing construction project being ceased along the way.

There are many abandoned projects, failed projects and on-going projects in Nigeria today. Some of the on-going projects have failed and abandoned for past many years, but due to the intervention of the clients (ie Federal/State Government, individuals), the construction is ongoing. Some construction projects still remain failed and abandoned, while, some have been revoked and rewarded to another contractors. Some of the awarded contracts, failed construction projects and on-going projects in Nigeria are: Lagos-Calabar Railway Project linking Lagos in the West to Calabar in the East at the cost of \$11billion USD; Mambilla hydroelectric power plant project connecting three dams across the Donga River in Taraba State at the cost of $\$ 5.8$ billion; the Ibeju Lekki Deep Seaports in the axis of Lagos at the cost of $\$ 1.2$ billon to be due for completion in the year 2021; the Eko Atlantic City which is a mega project built on Victoria Island and adjacent to Lagos, Nigeria; the Lagos-Ibadan standard gauge rail line at the cost of \$2.1billon USD; the Baro Inland Port Project in Agaie local government area of Niger state at the cost of \$5.8 billon has remained dormant eight months after commissioning by President Muhammadu Buhari due to non release of fund which had stalled its completion; the recent approval by Federal Government of Nigeria of the Ibadan to Kano standard rail project at the cost of $\$ 5.3$ billon; the cases of many failed and abandoned projects in the Niger Delta region of Nigeria in which investigation is on-going by the Chairman, House of Representatives on the Niger Delta Affairs, Mr. Nicholas Ossai; the Bacita-Kpandaragi -PatidzhuruTsaragi junction road in Edu L.G.A. of Kwara State which has failed and abandoned for more than thirty (30) years now without Government intervention if not in the year 2018 when it had failed culvert along the road that the Kwara State Government intervene in the rehabilitation; Jebba/Bacita Junction - Bacita township $18 \mathrm{~km}$ had failed and abandoned for more than thirty (30) years without Government intervention, since the inception of the first civilian governor of the state Late Alhaji Adamu Attah in 1979, who constructed the road half-way, since then it is the private individuals, and commercial drivers that normally go on skeletal rehabilitations, and yet to be awarded.

Adugbo and Shuaibu (2019) reported that the present administration at its inception in 2015 placed topmost priority to invest heavily on critical infrastructure with a target to do at least one road project per state. Available data shows that there are over hundred (100) road projects scattered across the country that the administration is either constructing newly or has been rehabilitating since 2015. Some of the on-going road projects the Federal Government under President Muhammadu Buhari has expressed clear commitment to finish include: the Lagos-Ibadan Expressway; the Kano-Maiduguri Highway; IlorinJebba Road; The second Niger Bridge and the AbujaKano Expressway. Also, among the projects that will receive massive funding in the 2019 budget are the dualisation of the Makurdi-Enugu Road in Benue and Enugu States and the dualisation of Akwanga -Jos Bauchi -Gombe Road in Nassarawa ,Plateau, Bauchi and Gombe States. Other on-going critical road infrastructure that will get government's attention this year include: the construction of Bodo -Bonny Road, with a bridge across the Opobo channel in River State; dualisation of Ilorin-JebbaMokwa/Bokani Junction Road in Kwara and Niger States and the dualisation of Suleja -Minna Road phase II in Niger State. Adugbo and Shuaibu (2019) findings also show that the rehabilitation of 73 kilometres single carriageway stretching from Odukpani through Ikom to Ogoja in Cross River State flagged off earlier this year and completion of work on the Loko -Oweto Bridge over River Benue which connects Loko and Oweto communities in Nassarawa and Benue States respectively are other top priory projects.

In the housing sector, the minister will have his hands full on how to bridge the housing gap in the country, which experts estimate has claimed up to \$20m despite all the efforts made so far. The housing sector is expected to leverage on the upscaled funding captured in the 2019 budget which shows the intervention of the government to pump in more money into the sector. In 2019, Government plans to spend $\$ 30.9 \mathrm{bn}$ on the construction/provision of housing under the Federal Government's on-going National Housing Programmed nationwide compared to 2018 when less than $20 \mathrm{bn}$ was budgeted by the government (Adugbo and Shuaibu, 2019). 


\section{International Journal of Engineering Applied Sciences and Technology, 2020}

Vol. 5, Issue 2, ISSN No. 2455-2143, Pages 679-692

Published Online June 2020 in IJEAST (http://www.ijeast.com)

According to Omorokpe et al. (2012), small business firm contributed immensely in a special way to the rapid economic development of a nation, but there are special problems usually faced by small business organizations. These problems can limit profitability and growth, decision to close the business voluntarily on financial insolvency. The most important problems usually experienced by small business owner are as follows: 1. competition from bigger companies; 2. poor sales return; 3. taxation (multiple levies and taxes); 4. Government regulations and official bottle-neck; 5. lack of skill Labour (both managerial and technical); 6. lack of capital base; 7. lack of business knowledge; 8. poor management; 9. inadequate planning; 10. lack of adequate control.

According to Sasi Kumar and Divakar (2018), the main causes of business failure are: delay in collecting debt from clients (donors); lack of capital; low profit margin due to high competition; border closure; heavy dependence on bank loans and payment of high interest on these loans; awarding contracts by client to the lowest bidder; absence of industry regulations; and lack of experience in contract management. He said that there are three (3) main factors namely financial, managerial, and external. The identified factors are ranked according to their importance as assessed by the respondents. The findings showed that the top five affecting factors are: fluctuation in construction material cost; delay in collection dibs from clients; low margin of profit due to completion; lack of experience in contracts. He examined the critical factors causing the failure of construction companies through a survey conducted among forty (40) small to mediumsized Turkish construction companies. A lack of business experience and country's economic conditions were found to be the most influential factors to company failure. Adugbo and Shuaibu (2019) proposed a new model to predict company failure in the construction industry. The model includes three (3) major innovative aspects. The use of strategic variables reflecting the key specificities of construction companies, which are critical to explain company failure. The most common unethical conduct evidenced by the contractors are cover pricing, bid cutting, poor documentation, late and short payments, subcontractors' lack of safety ethics, unfair treatment of contractors in tender/final account negotiations, competitors' overstatement of capacity and qualifications to secure work, competitors' falsification of experience and qualifications and bureaucratic, government policy (Adugbo and Shuaibu, 2019).

\section{OBJECTIVES OF THE STUDY}

- To examine the causes of construction project failure and abandonments in Nigeria.

- To proffer possible solutions to the causes of construction projects failure and abandonments in Nigeria.

- To assess the causes for the contractor's failures in the Nigerian construction industries and to suggest suitable recommendations to the contractors in order to overcome their failures.

\section{MATERIAL AND METHODS}

This research was carried on five hundred and twenty (520) people both in Kwara State and Niger State. This study was carried out from January 2019 to September 2019. A total number of 520 people were the respondents (both male and female). The research discuses the main causes of failure in contracts in Nigerian construction projects and the proffered possible solutions. The major causes of project failure in the Nigerian construction projects which were defined based on the cost overrun and time overrun are stated in the questionnaire and used to initiate the research. The objective of the research was achieved by means of questionnaire survey. The data on the study variables were obtained structured questionnaire from the countries which are located in Kwara and Niger States with a pool of experience in failed and abandoned projects. The questionnaires contain various causes of failure in Nigerian construction project which were distributed to people in some selected areas in Kwara and Niger States. Each respondent was instructed to tick/mark only one factors which he/she believes is the main cause of failure in construction project without regards to order in which they were stated in the questionnaire and based on their experience with construction projects. The data were collected and retrieved by approaching the respondent. A total of two hundred and sixty (260) questionnaires were distributed in each of Kwara State and Niger State and the same figure were retrieved from each state and were used for analysis.

The statistical analysis was done using the statistical tools such as descriptive statistics. These descriptive statistics included measures of central tendency mainly means. The results were presented using tables and bar charts to give a clear picture of the research findings. The possible solutions were proffered based on the experience with the construction firms, the clients and findings. 
International Journal of Engineering Applied Sciences and Technology, 2020

Vol. 5, Issue 2, ISSN No. 2455-2143, Pages 679-692

Published Online June 2020 in IJEAST (http://www.ijeast.com)

TABLE 1: QUESTIONNAIRE RESPONDENTS FROM KWARA STATE.

\begin{tabular}{|c|c|c|}
\hline $\mathbf{S} / \mathbf{N}$ & $\begin{array}{c}\text { Causes of } \\
\text { Contracts/Projects } \\
\text { Failure }\end{array}$ & $\begin{array}{l}\text { Numbers of } \\
\text { Respondents }\end{array}$ \\
\hline 1. & Corruption & 50 \\
\hline 2. & Poor Supervision & 8 \\
\hline 3. & Changes in Design & 12 \\
\hline 4. & Political Interference & 15 \\
\hline 5. & Poor Planning & 23 \\
\hline 6. & $\begin{array}{l}\text { Slow Decision } \\
\text { Making }\end{array}$ & 12 \\
\hline 7. & $\begin{array}{l}\text { Lack of Funds to } \\
\text { Finance the Project to } \\
\text { completion }\end{array}$ & 60 \\
\hline 8. & $\begin{array}{l}\text { Lack of Effective } \\
\text { Communication } \\
\text { among the Parties }\end{array}$ & 13 \\
\hline 9. & $\begin{array}{l}\text { Misplacement of } \\
\text { Priorities }\end{array}$ & 11 \\
\hline 10. & $\begin{array}{l}\text { Unqualified } \\
\text { Contractors }\end{array}$ & 4 \\
\hline 11. & $\begin{array}{l}\text { Unspecified Scope of } \\
\text { Work }\end{array}$ & 6 \\
\hline 12. & $\begin{array}{l}\text { Poor } \\
\text { Tendering/Selection } \\
\text { Procedure }\end{array}$ & 7 \\
\hline 13. & $\begin{array}{l}\text { Neglects of Bill of } \\
\text { Quantities (B/Qs) }\end{array}$ & 5 \\
\hline 14. & Security Challenges & 24 \\
\hline \multirow[t]{2}{*}{15.} & $\begin{array}{l}\text { Use of Sub-standard } \\
\text { Materials }\end{array}$ & 10 \\
\hline & Total & 260 \\
\hline
\end{tabular}

TABLE 2: QUESTIONNAIRE RESPONDENTS FROM NIGER STATE.

\begin{tabular}{|c|l|c|}
\hline S/N & $\begin{array}{l}\text { Causes of } \\
\text { Contracts/Projects } \\
\text { Failure }\end{array}$ & $\begin{array}{l}\text { Numbers of } \\
\text { Respondents }\end{array}$ \\
\hline 1. & Corruption & 56 \\
\hline 2. & Poor Supervision & 12 \\
\hline 3. & Changes in Design & 8 \\
\hline 4. & $\begin{array}{l}\text { Political } \\
\text { Interference }\end{array}$ & 11 \\
\hline 5. & Poor Planning & 10 \\
\hline 6. & $\begin{array}{l}\text { Slow Decision } \\
\text { Making }\end{array}$ & 70 \\
\hline 7. & $\begin{array}{l}\text { Lack of Funds to } \\
\text { Finance the Project } \\
\text { to completion }\end{array}$ & \\
\hline 8. & $\begin{array}{l}\text { Lack of Effective } \\
\text { Communication }\end{array}$ & 7 \\
\hline
\end{tabular}

\begin{tabular}{|c|l|c|}
\hline & among the Parties & \\
\hline 9. & $\begin{array}{l}\text { Misplacement of } \\
\text { Priorities }\end{array}$ & 5 \\
\hline 10. & $\begin{array}{l}\text { Unqualified } \\
\text { Contractors }\end{array}$ & 6 \\
\hline 11. & $\begin{array}{l}\text { Unspecified Scope } \\
\text { of Work }\end{array}$ & 5 \\
\hline 12. & $\begin{array}{l}\text { Poor } \\
\text { Tendering/Selection } \\
\text { Procedure }\end{array}$ & $\begin{array}{l}\text { Neglects of Bill of } \\
\text { Quantities (B/Qs) }\end{array}$ \\
\hline 14. & Security Challenges \\
\hline 15. & $\begin{array}{l}\text { Use of Sub- } \\
\text { standard Materials }\end{array}$ & $\mathbf{2 6 0}$ \\
\hline & Total & \\
\hline
\end{tabular}

\section{CAUSES OF CONTRACTS FAILURE IN NIGERIAN CONSTRUCTION PROJECTS.}

Findings revealed that causes of contracts failure are not peculiar to a particular reason but it cut across many reasons which are having adverse effects on the proposed, planned and developed projects located in different parts of the country. The joy and pride of the citizens is the completion of these earmarked development projects without any delay which add more values and beautify the built environment. The developmental projects that we are specific about which are of great concern is the infrastructural projects such as electricity, house, drainage, schools and roads. Among the causes of contracts failure in our construction projects are corruption, lack of funds to finance the project to completion, poor supervision, political interference, changes in design, misplacement of priorities, lack of effective communication among the parties, poor planning, slow decision making, unqualified contractors, unspecified scope of work, poor tendering/selection procedure, neglects of Bill of Quantities (B/Qs), security challenges and use of substandard materials.

- Corruption: This is an act which is contrary to the laid down rules and regulations in the execution of construction projects. In these corrupt practices, the available funds to initiate the projects is being diverted into personal use and embezzlement follows. These acts allow project failure to take place. According to Adekunle et al. (2019), corrupt practices have been found to be a key and 
unrelenting stumbling block to construction industries that are trying to achieve sustainable social and financial growth. It has become a general debate among the citizens because of its prevalence within various sectors thereby making the economy to crawl. In Nigeria today, corruption has consumed deeply into our system that it remains the greatest threat to the achievement of the desired and targeted growth. He defined corruption as receiving, asking for or giving any gratification to induce person to do a favour with a corrupt intent. It is important to note that other relevant issues such as bribery, fraud, fund misappropriation and the likes should be checked while addressing corruption. Ibrahim (2019) reported that the Kaduna State Government has concluded plans to revoke contracts awarded to contractors who have been mobilized but disappeared with the funds meant for the projects. The government said the affected contractors would be handed over to the Economic and Financial Crimes Commission (EFCC) for prosecution. Alkassim (2019) also reported the ongoing corruptions in the Niger Delta Development Commission (NDDC) in which the contractors handling projects in the Niger Delta alleged that the Niger Delta Development Commission engaged in sharp practices. The contractors spoke separately at a public hearing organized by an adhoc committee set up by the House of Representatives to investigate cases of abandoned projects by the NDDC over the years. They were invited to testify and make submissions on contract details by the Ossai Nicholas Ossai-led adhoc committee on failed contracts and abandoned projects awarded by the commission since the years 2000. They alleged 1 connivance by banks and some elements in the NDDC to bargain for "cuts" from contractors. One of them, Fubara Blessing, asked the committee to investigate the NDDC activities to ascertain the level of sleaze and compromises stalling contracts' execution in the Niger Delta. He accused the NDDC of awarding dubious, emergency and unaudited contracts to extort money from contractors. While investigating the on-going corrupt practices in the NDDC, Matazu (2019) reported that the senate committee on Niger Delta yesterday rejected the 2020 capital budget of \#23bn for the Ministry of Niger Delta Affairs. The committee cited non-completion of projects in the region. The committee's chairman, Peter Nwaoboshi, who made his speech when the Minister of the Niger Delta Affairs, Godswill Akpabio, appeared to defend the 2020 budget of the ministry, said it was discovered during an oversight function that so many projects were abandoned across the nine Niger Delta States. The chairman said that there is no state or local government where there are no abandoned projects in the Niger Delta and we cannot continue like that. "With all the abandoned projects in the Niger Delta and we are talking about new projects; these new projects are designed to fail", the senator declared. In this case, the fund released for the previous years capital budget had be mismanaged.

- Lack of Funds to Finance the Project to Completion: The cost overrun is an important measure of project failure. Insufficient funds released have stalled many projects not allowing it to reach completion. This is evidenced in most parts of the country that failed and abandoned projects littered everywhere. This problem may arise from either the clients (e.g Federal Government, State Government, Private Individuals) or the contractors (i.e construction companies). Research showed that some of the contractors even disappeared despite funds were released to initiate the project execution. According to Mukeshchandra et al. (2018), construction industry requires huge capital to build an infrastructure and technological advancement also needs to be updated. Ibrahim (2019) reported that Commissioner for Education in Kaduna State, Dr. Shehu Makarfi, disclosed at a meeting with some of the contractors on the problems affecting execution of the projects. A government document shows that the projects awarded at the cost of over \$6.35bn were mainly construction, renovation, and rehabilitation of classrooms. Others are the construction of drainage system, solar-powered boreholes, toilets, supply and installation of solar streetlights, supply of furniture, as well as construction of perimeter fences. The Commissioner said the percentage of completion of the projects range from 0 to 80 percent, and that only four of the projects were 100 percent completed, adding that this was despite about $\$ 2.31$ bn so far disbursed to the contractors. He said the state government had concluded plans to pay outstanding contract liabilities, but noted that some of the contractors were not doing very well while others just collected mobilization fee and disappeared. According to Ajobe amd Sule (2019), this lack of fund had led to the abandonment of Baro Inland Port before the Buhari Administration forged ahead to deliver it. The contractor returned to site after an initial release of fund by the Buhari administration but the progress has been slow due to failure to advance additional fund for the project. 
- Poor Supervision: Inadequate supervision always lead to poor supervision and the consequence is always poor project delivery. This normally occur due to inadequate training given to labourers used in construction sites as it is seen in Nigeria construction industry that there are thousands of labourers works directly and indirectly in which most of them are unqualified, unskilled, and untrained.

- Political Interference: The change of power every four years in Nigeria since the inception of democracy in 1999 has made so many projects become failed and abandoned. The worst part of is some on-going projects became ceased and stalled. The present government may initiate a project and it is on-going, but, by the time the period of four (4) year (or 8 years if reelected) elapses, the successor may not interfere with the project initiated by his/her predecessor. This attitudinal behaviour has made so many projects to become failed and abandoned. In Niger State, the mega shopping complex project located at the centre of Minna, the state capital, was initiated and executed by the former governor Dr. Muazu Babangida Aliyu in 2014, but after his tenure ended in 2015, his successor that took over from him since May 2015 did not interfere with the project which has become failed and abandoned up till date. Research showed that some other state governors are able to continue from where their predecessor stopped. Moses (2019) reported that Ogun State Governor Dapo Abiodun say a $\$ 26$ billion debts is making the completion of the Lagos-OtaAbeokuta road project difficult. Abiodun, however, said that he and his Lagos counterpart, Babajide Sanwo-olu had written to President Muhammadu Buhari to take over the project and two other federal roads; Epe-Ijebu and Ikorodu-Sagamu. He said the roads, if completed, would reduce pressure and population of motorists plying ever - busy Lagos-Ibadan expressway.

- Changes in Design: This is a common and popular problem to be encountered in construction industry. In construction projects, a change refer to a modification or an alteration to pre-existing basic information, conditions, requirements and assumptions. This consists of time, cost, work, and method of performance. Design changes and rework are inevitable in construction projects so it shouldn't be a surprise to any worker be it skilled or unskilled. It is in every construction project that this change normally takes place but the level of changes differs from project to project. This makes the client to spend above the initial estimation which results in argument, misunderstanding, disputes in construction site and unnecessary delays occur due to changes.

- Misplacement of Priorities: Project execution involve multi-tasks/many activities which may be in sequential order. Any obstruction to this sequential order can lead to project failure because one task has to be carried out before the next one. According to Nagarajan (2012), in project preparation, the first task is to identify a project that prima-facie appears to be a worthwhile project, the project promoter has to further analyze the project to ensure that it has the potential and the investment on it would not go waste, but would yield attractive returns. The project preparation consists of four states which are: 1. Pre-feasibility study 2. Functional studies (or support studies) 3. Feasibility study 4. Detailed project analysis (leading to the preparation of Detailed Project Report). These priorities must not be misplaced.

- Lack of Effective Communication among the Parties: The existence of effective communication is very important between the clients and contractors. Communication gap and communication barrier contribute to project failure. The client and contractor need to understand each other so as to allow smooth project execution and avoid failure. Even among the project team members who work with the project manager in completing the project, the absence of effective communication among them will lead to project failure, project delay and poor project delivery at the end. So the client and contractor need to carry each other along the way as the project execution progresses and the project manager also should carry his/her project team members along.

According to Kasimu and Kolawale (2019), knowledge is scattered in the construction phase of projects and the pool of knowledge is lost, if there is no proper channel of sharing the knowledge generated during the construction phase of projects to other employees for re-use. Sharing of knowledge across a project is equally important, since the knowledge transfers from a current to concurrent or subsequent projects so as to allow employees to use existing proven knowledge to solve problems as a substitute of creating a new knowledge, which can meet up with time. When an organization has deficiencies in a heightened degree of knowledge sharing, knowledge leaks are the consequences. Therefore, such leakage ultimately results in an organizational inefficiency like repeated mistakes, depending on a few key individuals, duplicated work, lack of sharing of good ideas, slows in the adoption of new ideas, techniques, and technical know-how 
and problems solutions. Knowledge sharing is the heart of knowledge management practice. If professionals do not share what they know, then there is generally a little knowledge to be managed. The concept of knowledge sharing is to create a knowledge sharing atmosphere whereby knowledge sharing is power, as opposed to the ancient belief that "knowledge is power". The construction firms/industries in Nigeria are still being criticized of continuous mistakes and errors during the construction phase of the projects, disputes, poor planning and design, time and cost overrun, and poor quality of workmanship. This showed that knowledge and professional experiences are not shared among the employees for re-use due to some impediment called barriers (Kasimu and Kolawale, 2019).

- Neglects of Bill of Quantities (B/Qs): It is an important document in construction project. When a project is to be embarked upon, there is need for the preparation of bills of quantities in which the agreed sum becomes the contract sum on which tenders are floated for tenderers to tender. Specifications and bills of quantities are the main documents prepared by construction firms. Any attempt to neglect the bills of quantities and not following it according to specifications in project execution results into project failure. Alterations to the bill of quantities by the contractors without the consent of the clerk and client also results into failure. One of the major criteria by which a success of building projects are measured is the cost performance. In construction projects, the bill of quantities has become an important document in construction activities and project execution. Therefore, bill is an account of workdone or supplies made specifying the actual quantities of work done or supplies made, their rates and amounts due to the contractor/supplier.

- Poor Planning: Many projects do end successfully, while, many others do end resulting to disasters and misunderstanding. Inadequate project definition and planning has created a lot of mistakes in construction projects. The consequence of poor planning in any construction project is project failure. This poor planning normally occur as a result of non-schedule of time to define the project objectives, scope, assumptions, risks, budget, timeline, organization, project time delivery, and overall approach. To avoid project failure, all these have to be defined before the actual work of the project begins. Additionally, poor budgeting specifically has stalled many projects in Nigeria. It is used that a project needs to have a budget and deadline before the business requirements are completed. In many cases, if the definition and planning are not done ahead of time, the project team starts off with inadequate resources and time and it is not realized until the project is already in progress. Many projects that could be successful are being seen as failures because their budgets and deadlines were being overshot. This situation is often caused by the project manager committing to numbers that are too low, based on a lack of up-front planning. Most of our highways in Nigeria are not in good conditions. This is due to poor planning and inability to identify the risk factors affecting highway construction project and al the risks that may be faced during highway construction.

According to Reshma and Sreechithra (2018), highway construction projects carry some substantial risk. Risk management is an important factor in project management. The first step of risk management is risk identification stage. Risk management includes the processes concerned with identifying, analyzing, and responding to road project risk. It includes maximizing the results of positive events and minimizing the consequences of adverse events. However, until now most researches have focused on some aspects of construction risk management rather than using a systematic and holistic approach to identify risks and analyze the probability of occurrence and impact of these risks. Indian highway construction projects are associated with different levels of risks. The objective of the risk management in highways are as follows: a. To identify the various risk factors in highway projects b. To understand the concept of risk management $c$. To investigate how the sector manages risks d. To facilitate the use of Risk Management (RM) focused on the highway construction.

- Poor Tendering/Selection Procedure: A tender is a submission made by a prospective supplier in response to an invitation to tender. It makes an offer for the supply of goods or services. Tender documents are prepared to seek tenders (i.e offers). Administrative errors such as failing to sign the tender, or not submitting in the format requested, along with submission errors such as failure to submit on time, or submission to the wrong person, can all lead to tender failure which results to initial stage of construction project failure as a whole. Failure to communicate tender to the buyer, poor writing that is hard to follow, difficult to understand, and answers that are poorly explained, are all the main reasons why the contracts may become failed. There are some common mistakes that can be made when tendering for construction 
projects which can harm the chances of the bid being successful. Since every construction site differs from one another, failing to visit it prior to submitting a tender can mean that the bidder does not have a comprehensive understanding of the requirements of the project, the needs of the client, and the likely conditions that will need to be considered within the bid. This can also be a problem if the bid is successful and issues become apparent once work begins which results into the construction project failure at the end.

According to Khanal (2019), construction contractor selection criteria are governed by public procurement rule, criteria are governed by clients and management team. Therefore, to select the good contractor for construction works, management team should continue the procedure extremely. While comparing the country Nepal with others, he said in Nepal, Government normally issue the public procurement rules to select the contractor. According to these rules, they are giving the most priority to lowest bidder among the pre-qualified bidder. This lowest bid system sometimes produces the huge problems in construction industries to completing works on time. Therefore, there are current and other alternative methods to select the contractor so as to avoid the delay of works.

Khanal (2019) concluded that there are different methods which are currently practiced in the world today related to a selection of the contractor for construction work. Among those methods, is the low bid selection method which is one of the selection procedure used in Nepal. This method is currently used in Nepal. Sometime it will be difficult to find out the capable contractor using this method. If the appropriate contractor is not selected according to the nature of works, construction work will be delayed and cost overrun. Time schedule delay and cost overrun will have bad effect in all project. Quality of the work will become decreased, dispute and arbitration will be created between the client and contractor. Delay of works will have adverse effect on the environment and daily activities of the people. Also, it will decrease the economic growth of the country (Khanal, 2019).

- Unqualified contractors: Construction projects are not what anybody can just interfere with. They are the projects that require the knowledge, skill, and ability of the right workforce and professionals that will execute the project according to design and specifications. It is unfortunate today that at the initial takeoff of construction projects, some of the contractors show much interest on the released funds and initial mobilization fee instead of employing the qualified workforce and professionals that will carry out the project execution. In this case, the employed workforce is now based on availability neglecting competency and the right skilled people. So, the use of any unqualified contractor on any construction project will always yield poor project delivery and to the dissatisfaction of client at the end. Kasimu and Kolawale (2019) asserted that construction firms/industries are not in possession of any available platforms to support the professionals to exchange and share the knowledge during the construction phase of the projects. The failure to share the knowledge represents a main loss for firms/industries. Knowledge is kept within the heads of professionals who develops it and hard to access by others. The amount of knowledge loss is high when the professionals move from one firm to another especially in the case of Nigerian construction firms/industries where the professionals are discarded after completion of construction projects. When the professionals finish the execution of the construction projects or leave the company, they usually take their domain knowledge with them and leave little or nothing to be benefited for future projects (Kasimu and Kolawale, 2019),

- Unspecified Scope of Work: To define the major characteristics of a project up-front is very important. When this is not done, there will be differences in expectations among the major stakeholders. When some of the contractors are not able to be specific on the scope of work, most of the time it affects the project execution. One of the major aspects of defining a project is defining the high-level scope. If this is not define and gain agreement on scope, the contractor will find it very difficult to manage scope effectively throughout the project execution. When the professionals do not know the scope of the work, there can't be effective project execution. In this situation, there can't be any stipulated designs and specifications. Also, different conceptions about the project by the contractors and other stakeholders which can lead to changing the scope of the work in the middle of the project execution can be dangerous/risky and if it is not properly handled can lead to additional request of funds and unnecessary delays.

- Security Challenges: The security of a construction site has been a major concern to the contractors, clients, and other stakeholders. The theft in the construction site has become a major problem which keeps on growing day by day. Theft and petty crimes such as vandalism is so rampant in construction industry which has contributed much to the project/contract failure and delays. The 
construction sites have become attractive places for thieves due to expensive items such as materials, tools, equipment, machinery, and lack of security. Any unprotected construction sites gives room to equipment theft, and substantial quantities of construction materials are being stolen from the construction sites. So, this construction theft has added a certain percentage to the cost of a project in the construction industry and this has to be averted. Also, Boko Haram insurgency which is a natural calamity and an insurrection that cannot be defeated by use of force. This has become a threat and big problem to the construction industry. This insurgency has lasted over ten years now which is affecting the activities of construction industry and project execution in Nigeria, more especially in the North-East geo-political zone of Nigeria which is the seat of Boko Haram insurgency. Some of the construction workers refused to operate in this area and the few that operates do that with fear. This has made some construction projects to fail and project execution stalled in this area/region. Also, kidnapping is so rampant everywhere in the country today. Construction workers operate with fear and foreign investors find it difficult to invest and operate in the country to avoid being kidnapped.

- Use of Sub-Standard Materials: The substandard materials and design error are the major causes of component failure. It is seen that failure occur due to negligence or gross human error. This is more evident in building and road construction projects. The use of sub-standard construction materials, poor performance of work and incompetency of workers have caused a lot of failures in our construction projects. The issues of building collapse, bridge collapse, failed sections of roads, and unmotorable roads are so rampant in the country.

- Slow Decision Making: There are a lot of happenings in the construction process. These take place through decision making. These decisions are taken by the superintendents, project managers and people in the office. In construction firms, construction decision making relies on experience and data. The more the two are utilized, the better the decisions taken. They enhance good decision taken. But, it is unfortunate today that some construction project become failed due to slow decision making. There may be some decisions made at any particular stage that are not reflecting the activities that are being undertaken at that stage, such decisions will slow down the project execution, cause unnecessary additional costs, project/contract failure, delays in project delivery and result in to poor project delivery. Therefore, the prompt decisions to be made on projects should be well structured, ordered, and controlled so as to ensure successful project execution and good project delivery.

According to Khanal (2019), contractor selection procedure and decision making criteria are the most important tasks for clients and management group. The contractor is one of the major cause to complete the work on time with good quality of works. To make a decision for selection, the contractor depends on public procurement of rules and procedure of Nepal. Therefore, public procurement rule should be practical, competitive and qualitative. Careful analysis and selection of construction contractors, including bid participation, bid evaluation, and final selection are important management responsibilities news for attaining successful results.

\section{PROFFERED POSSIBLE SOLUTIONS}

Failure of projects is a costly affair and will destabilize the organization as a whole (Nagarajan, 2012). It does not bring success to the country and could lead to economic depression. To avoid this menace, there is need to proffering possible solutions which are as follows:

- Government Intervention: The government need to call on the contractors so as to go on mutual agreement so that the failed and abandoned projects will reach completion stage. This is possible if both parties able to reveal the cause of the failure and resolve amicably. Ibrahim (2019) reported that the Kaduna State Ministry of Education has met with contractors to ensure the completion of fifty-five (55) on-going capital projects in the sector awarded between 2016 and 2017.

- Good and Adequate Supervision: There are many construction activities tasks that are being carried out in construction project. There are thousands of labourers that are working directly and indirectly on the various construction industries in Nigeria in which most of them are not professionals, but they are untrained, unskilled, and unqualified workers. With these stated problems, there is need for extra co-ordination, training and supervision for these workers in the site so as to allow perfect tasks being carried out and ensure good project delivery. Adequate supervision during the construction is very important as it reveals indicators to other factors may likely cause potholes on highways, failed culverts and bridges, buildings collapse, 
bridge collapse, failed sections (e.g gullies) of the roads etc. Adequate supervision always produce quality job as it is known that construction projects has life span especially road construction and equipments, as the quality of supervision depends on the skills of the supervisor.

- Strict Adherence to Design and Specifications: Some clients are not experts, but they like expressing their opinions along the way which is contrary to the initial project designs authenticated by the contractors and consultants. This is the main cause of changes in design. The clients and contractors need to work collectively and amicably to avoid frequent changes in design and strictly adhere to the design specifications. The design change is an important factor hindering the performance of construction projects. It retards the success, completion and delivery date of project as scheduled/specified on the contract document. Therefore, it is recommended that the spirit of teamwork should exist amongst the stakeholders involved in the project and respect to original design by the clients as the man ingredients for a successful project delivery.

- Revocation of Contracts: This is the withdrawal of a contract awarded to a contractor by a client due to the poor performance or the disappearance of the contractor after the collection of mobilization funds without the consent of the client or failure in the project delivery time. When contract/project failure like this occur, such a contract should be revoked and re-awarded to another construction firm. According to Ibrahim (2019), as in Kaduna State, for those projects that the contractors do not perform up to expectation, and those that collected mobilization funds but disappeared, the Commission for Education, Dr. Makarfi, said such contracts would be revoked and the affected contractors handed over to EFCC. Ajobe and Sule (2019) reported in the Baro Inland Port Project, that there are two transport network which are road and railway but are stalling activities of the port. The two major access roads to the ancient community: the 55 kilometres Baro/Katcha/Agaie and Baro/Muye linking Gegu on Abuja/Lokoja expressway, both of which are in deplorable conditions. The Federal Government awarded the contract for the Baro/Katcha/Agaie axis in 2009 but revoked it in 2012 due to alleged failure on the part of the contractor to deliver on time. However, the contract for the road was reawarded few months to the 2015 general elections to an Indian firm at the cost of 117.5 billion with a 12 months completion period
- Establishing good collaboration among the project relevant stakeholders involved in a construction project at the early stage of project conception is most in order to accomplish the project objectives, and deliver the project on time within budget and quality specified in the original contract document.

- Good Planning: Before embarking on any construction projects, the contractors and clients must have a complete definition and planning process before starting to gather the business requirements. They need to have good and proper planning by ensuring that the work is properly understood and agreed to together with other stakeholders. They need to work together and allow cordial relationship to exist among them so as to ensure that there is a common perception of what the project will deliver, when it will be completed (i.e project time delivery), what will it cost, who will do the work, how the work will be done, and what the benefits will be. All projects should commence with type of up-front planning so as to prevent problems caused by different viewpoints on the basic terms of the project. Therefore, project must be defined properly and all expectations must be identified before the project can begin.

Mukeshchandra et al. (2018) stated that spending sometime to learn planning techniques and implementing it on the site will also help in one way or the other in the construction methods. Building an infrastructure needs a proper planning. To plan a construction project, project manager must be well versed with the latest scheduling techniques, new construction methods and quality tools.

- Competitive tendering should be allowed to take place. It is often considered to promote competition, provide transparency and give all details. A competitive tender is a tender that can compete with other tender proposals in terms of price, quality and delivery, meeting all the requirements of the buyer. Also, tender documents should be broken down into a series of packages, each having it own design drawings and specifications suitable to be issued by the main contractor to potential sub-contractors. When this is done, it will ensure that the interfaces between packages are properly indentified and clearly allocated to one package or another. Also, a clear proposal should be written with good writing skills. These are done to avoid project failure.

- Leaning from the previous failed projects, how those projects failed, and the reasons for their failures. This will help project managers to plan 


\section{International Journal of Engineering Applied Sciences and Technology, 2020}

Vol. 5, Issue 2, ISSN No. 2455-2143, Pages 679-692

Published Online June 2020 in IJEAST (http://www.ijeast.com)

and mitigate the risk involved in project failure in the future.

- There is need to call the attention of the various disciplines of the Nigeria Society of Engineers (NSE), not just the construction industry, to start working with the Standards Organization of Nigeria (SON) and the senate of the country to produce local codes of practice and appropriate bye-laws that will regulate all aspects of design, approval, construction, repair and maintenance of building and other construction facilities and services in the country.

- Organizing workshops and seminars will help to educate and enlighten clients, contractors, users, architects and engineers on what is project failure, the factors contributing to abandoned and failed contracts/projects and their causes.

- The professional institutions such as Council for the Regulation of Engineering in Nigeria (COREN) NSE, Nigeria Institution of Civil Engineers (NICE), Nigeria Institution of Highway Engineers (NIHE), Nigeria Institution of Mechanical Engineers (NiMeche),etc. and SON are therefore requested to be more serious at checking the level of enforcement of international codes of practice or develop local equivalents for construction materials, vendors for quality control and standardization.

- As security challenges take different form in construction industry, in order to curb theft, the access of people to the construction site need to be minimized or controlled. This could be done by controlling the access to the site at the gate involving signing in and signing out of both the site workers and visitors, constructing exterior barriers such as fences or natural obstacles. Also. inventory of equipment, machinery, furniture and other items in the construction site should be taken daily so as to checkmate theft and in case any stolen item. On the other aspect of Boko Haram insurgency, the Federal Government needs to quickly constitute reconciliation committees that would involve stakeholders from the across the country who would ascertain the actual demands of Boko Haram group, and this logjam could be resolved through dialogue rather than shooting, bombing, and killing.

Also, on the frequent on-going kidnapping all over the country, the military men; policemen; and other Para-military men have been making collaboratory efforts to rescue the kidnapped people and prevent kidnapping in the country. So by making all these efforts, the construction workers will have rest of mind to carry out their tasks and more foreign investors would be attracted to come to the country.

\section{RESULTS AND ANALYSIS}

The questionnaire respondents from Kwara State is shown in the table 1 and the questionnaire respondents from Niger state is shown in table 2. The mean number of respondents is calculated from the data in table 1 and table 2 for each of the causes and later presented in the table 3. It is seen from the table 1 and table 2 that lack of funds to finance the project to completion has the highest number of respondents in each of the table indicating the main causes of failure and followed by corruption. Also, the table 1 and table 2 show that factors such as neglects of bill of quantities, unqualified contractors, misplacement of priorities, poor tendering/selection procedure causing failures in construction projects can be easily tackled and solved by educating and enlightening clients, contractors, engineers, architects and users. It is seen from table 3 that lack of funds to finance project to completion has the highest mean number of respondents, while use of unqualified contractors in the construction site has the least. From the table 3, it is seen that corruption is another main factor retarding the success of construction projects in Nigeria and it is a serious menace which needs to be averted. The mean number of respondents were recorded and plotted against the various causes of contracts/projects failure which is depicted in figure 1 below. The figure 1 compares the mean number of respondents among the various causes of contracts failure in Nigeria construction projects. It is seen that largely, lack of funds to finance project to completion has highest mean, and this is followed by corruption, this make the two unique when compared to other causes indicating that they have comparatively higher mean number of respondents. It was possible to conclude that lack of funds and corruption has much negative impacts on the success of Nigerian construction projects and these problems need to be tackled so as to allow infrastructural and societal development of the country. The findings imply that stakeholders, project users, citizens and some private owners are unhappy with the situation of projects failure such as collapsed building, collapsed bridges, poor state of roads, failed section of roads, and abandoned projects which is affecting the socioeconomic development of the country. 
TABLE 3: MEAN NUMBER OF RESPONDENTS IN BOTH NIGER AND KWARA STATE OF NIGERIA.

\begin{tabular}{|r|l|c|}
\hline S/N & \multicolumn{1}{|c|}{$\begin{array}{c}\text { Causes of } \\
\text { Contracts/Projects } \\
\text { Failure }\end{array}$} & $\begin{array}{c}\text { Mean Number of } \\
\text { Respondents }\end{array}$ \\
\hline 1. & Corruption & 53 \\
\hline 2. & Poor Supervision & 10 \\
\hline 3. & Changes in Design & 10 \\
\hline 4. & Political Interference & 13 \\
\hline 5. & Poor Planning & 19 \\
\hline 6. & Slow Decision Making & 65 \\
\hline 7. & $\begin{array}{l}\text { Lack of Funds to } \\
\text { Finance the Project to } \\
\text { completion }\end{array}$ \\
\hline 8. & $\begin{array}{l}\text { Lack of Effective } \\
\text { Communication among } \\
\text { the Parties }\end{array}$ \\
\hline 9. & $\begin{array}{l}\text { Misplacement } \\
\text { Priorities of }\end{array}$ \\
\hline 10. & Unqualified Contractors & 8 \\
\hline 11. & $\begin{array}{l}\text { Unspecified Scope of } \\
\text { Work }\end{array}$ \\
\hline 12. & $\begin{array}{l}\text { Poor } \\
\text { Tendering/Selection } \\
\text { Procedure }\end{array}$ \\
\hline 13. & $\begin{array}{l}\text { Neglects of Bill of } \\
\text { Quantities (B/Qs) }\end{array}$ \\
\hline 14. & Security Challenges & 6 \\
\hline 15. & $\begin{array}{l}\text { Use of Sub-standard } \\
\text { Materials }\end{array}$ \\
\hline
\end{tabular}

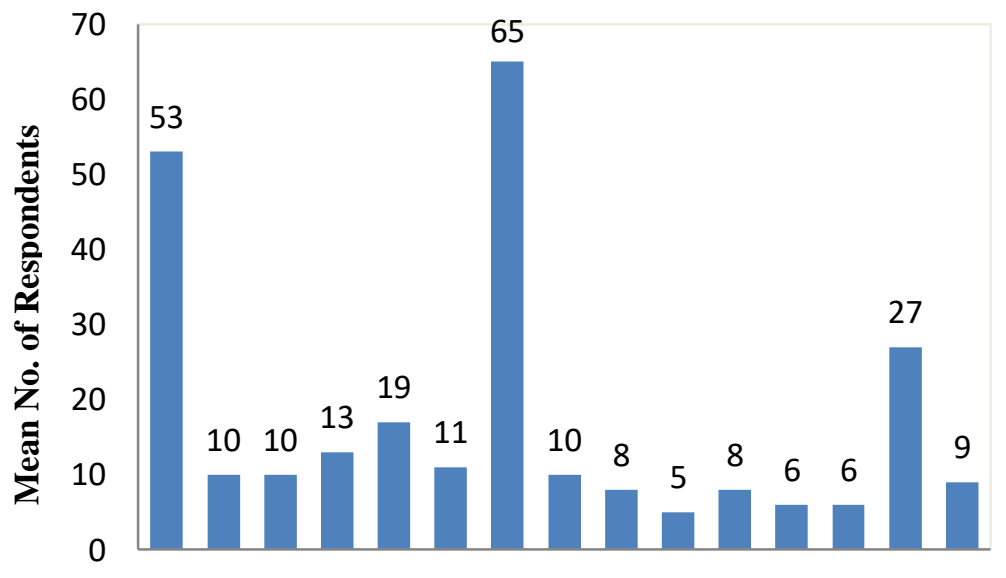

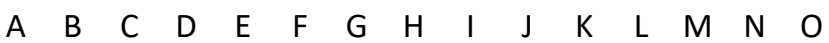

Causes of Contracts Failure

Figure 1: A bar chart showing the mean no. of respondents between Kwara State and Niger

State of Nigeria
A. Corruption

- B. Poor Supervision

- C. Changes in Design

D. Political Interference

E. Poor Planning

- F. Slow Decision Making

- G. Lack of Funds to Finance the Project to Completion

- H. Lack of Effective Communication among the Parties

- I. Misplacement of Priorities

- J. Unqualified Contractors

- K. Unspecified Scope of Work

- L. Poor Tendering/Selection Procedure

- M. Neglects of Bills of Quantities (B/Qs)

- N. Security Challenges

- O. Use of Sub-standard Materials

\section{CONCLUSION AND RECOMMENDATIONS}

Construction projects in developing countries such as Nigeria requires much labour. Case study has been conducted in two different states of Nigeria which are Niger and Kwara states in the North Central of the country to identify the severity of the causes of contracts/projects failure experienced in the environment of the residents of each of the state. The results of the research show that unqualified, unskilled and untrained labourers normally used in the construction site. As a result of this, extra coordination and supervision is seriously needed so as to guide them and achieve good project delivery. The success achieved in completing construction sites activities/tasks right from the beginning to the end depends heavily on the quality of supervision. Therefore, project managers need to ensure quality supervision and good quality control in the project execution.

The study recommended that the project managers should collaborate with the Standard Organization of Nigeria (SON) in order to ensure good quality control in all construction activities especially in the use of construction materials. This study needs to be updated for every four years in order to identify the recent causes of failure in contracts in Nigerian constructions projects and proffering possible solutions.

It is recommended that the management of the construction industries should partner with the military men, policemen, para-military and other 
security agencies so as to secure and protect the construction workers as the spate of kidnapping in the country is rampant and affecting the economy as the payment of ransom running into millions is being demanded before the release of any kidnapped person which is making Nigerians poorer.

\section{REFERENCES}

1. Ibrahim H. (2019). Kaduna govt to blacklists contractors, revives $\$ 6.35 \mathrm{bn}$ projects. Daily Trust Newspaper, Media Trust Nigeria, Limited, (Vol. 48. No.61, pp.42).

2. Halpin D.W. and Senior B.A. (2012). Construction Management, Fourth Edition, John Wiley \& Sons, Inc., New Jersey, (pp. 14-15, 63).

3. Sasi Kumar A. and Dr. Divakar K. (2018). Critical Causes of Failure in Contracts in Indian Construction Projects. International Journal of Innovative Science and Research Technology, (Vol. 3 No. 5, pp. 543-546).

4. Omorokpe R.O.; Nomuoja J.O. and Okieruovo L.E. (2012). Essentials of Small Business Management, First Edition, March Publishers, Otefe - Oghara, (pp.8-9).

5. Adugbo D. and Shuaibu U.M. (2019). Abandoned, Ongoing FG Projects may top Fashola's list. Daily Trust Newspaper, Media Trust Nigeria, Limited, (Vol. 48 No. 56, pp. 28).

6. Mosses P. (2019). \$26bn debt stalling Abeokuta road project-Gov Abiodun. Daily Trust Newspaper; Media Trust Nigeria, Limited, (Vol. 48 No. 61, pp. 7).

7. Ajobe A.T. and Sule I.D. (2019). 8 months after commissioning Multi-billion naira Baro Port dormant. Daily Trust Newspaper, Media Trust Nigeria, Limited, (Vol. 48 No. 61, pp. 1,6).

8. Nagarajan K. (2012). Project Management, Sixth Edition, New Age International Publishers, New Delhi, (pp. 26, 382-383, 550).

9. Alkassim B. (2019). N/Delta: Contractors indict NDDC over projects. Daily Trust Newspaper, Media Trust Nigeria, Limited, (Vol. 48 No. 72, pp. 3).

10. Matazu H.K. (2019). Senate rejects $\$ 23$ bn N/Delta Ministry budget proposal. Daily Trust Newspaper, Media Trust Nigeria, Limited, (Vol. 48 No. 92, pp. 3).

11. Umsohi F.A. and Imaroh T.S. (2020). Analysis of Scheduling Effectiveness and Project Delay Factors in Project Q. International Journal of Innovative Science and Research Technology, (Vol. 5, No.2, pp. 676-679).

12. Khanal B.P. (2019). Contractor Selection Method for Construction Work and its Effect in
Nepal. International Journal of Innovative Science and Research Technology, (Vol. 4, No. 12, pp. 141-146).

13. Adekunle A.; Adewale A.K.; Olaifa O.A. and Ukoh S.N.B. (2019). Statistical Study on Types, Causes, Effects and Remedies of Corrupt Practices in Construction Industries in Nigeria. International Journal of Advances in Scientific Research and Engineering, (Vol. 5, No. 9, pp. 71-80).

14. Mukeshchandra N.; Balapgol B.S. and Patil A.R. (2018). Alleviating Time Overrun with the Implementation of Critical Project Management in Construction Industry. International Journal of Innovative Science and Research Technology, (Vol. 3, No. 7, pp. 648-653).

15. Reshma P. and Sreechithra P. (2018). Risk Modeling in Highway Construction Projects. International Journal of Innovative Science and Research Technology, (Vol. 3, No. 4, pp. 445447).

16. Kasimu A.M. and Kolawale A.F. (2019). The Barriers to Knowledge Sharing Practice in Nigerian Construction Firms. International Journal of Advances in Scientific Research and Engineering, (Vol. 5, No. 9, pp. 26-33). 